\title{
Management of Purple Blotch Complex in Onion Seed Crop in Faridkot district of South-Western Punjab
}

\author{
Gurdarshan Singh* and Jagdish Grover \\ ${ }^{1}$ Krishi Vigyan Kendra, Faridkot, India \\ *Corresponding author
}

\section{A B S T R A C T}

\section{Keywords}

Fungicides,

Management,

Onion, Purple

blotch complex,

Benefit: Cost ratio,

Triazole

Article Info

Accepted:

18 January 2020

Available Online:

10 February 2020
Four systemic fungicides viz., Folicur 25 EC (tebuconazole), Tilt 25 EC (propiconazole), Score 25 EC (difenoconazole), Amistar Top 325 SC (azoxystrobin 18.2\% + difenoconazole $11.4 \%$ ) and one non-systemic fungicide viz., Indofil M-45 75 WP (mancozeb) were evaluated under field conditions for their efficacy to manage purple blotch complex of onion caused by Alternaria porri and Stemphylium vesicarium. Field efficacy of the fungicides at different concentrations was determined in controlling the purple blotch complex of onion seed crop (cultivar PRO-6) during the Rabi season 201516 and 2016-17. The field trial was conducted in Randomized Block Design (RBD) with six treatments along with four replications. All the recommended agronomical practices were followed during experimentation. The bulbs were planted during first fortnight of November at spacing of $67.5 \mathrm{~cm} \mathrm{X} 45 \mathrm{~cm}$. Foliar application of fungicides was started as soon as first symptom of the disease was noticed followed by three sprays at 15 days interval in bulb seed crop. The triazole fungicides, tebuconazole and difenoconazole proved superior in inhibiting growth of $A$. porri and $S$. vesicarium under field conditions. Four foliar sprays of tebuconazole 25 EC (Folicur) @ 0.1 per cent at fortnightly interval most effectively managed purple blotch complex in onion seed crop under field conditions with highest Benefit: Cost ratio (91.9:1). The present findings can go a long way in devising strategy for the integrated management of A. porri, S. vesicarium singly as well as in combination with other fungicides

\section{Introduction}

Onion (Allium cepa L., 2n=16), a bulbous, biennial herb is the most important and one of the five most important fresh market vegetables worldwide (Cramer, 2000). Among vegetables, onion often called as "queen of kitchen" is one of the oldest known and an important crop grown in India. It contains the lachrymatory principle, a strong antibiotic having fungicidal, bactericidal and nematicidal properties (Purseglove, 1972). In the world, onion crop is grown in about 5.30 million hectare area with an annual production of 88.48 million tons with productivity 16.70 tons per hectare. China 
stands first in onion production (22.61 million tons from an area 1.03 million hectares area) in the world with productivity 21.85 tons per hectare followed by India. In India, onion crop is grown in about 1.20 million hectare area, with an annual production of 19.40 million tons with productivity 16.12 tons per hectare (Anon, 2017). Purple blotch, commonly known as leaf blotch, caused by Alternaria porri is noted as the most serious disease of onion affecting both bulb and seed production by breaking of floral stalks (Ahmed and Hossain, 1985, Munoz et al., 1984). Stemphylium vesicarium, the causal agent of white blotch of onion is indirectly involved with the causation of purple blotch of onion. Stemphylium vesicarium initiates the infection and Alternaria porri facilitates for causing purple blotch and hence the disease is treated as purple blotch complex.

The low productivity of onion in India is chiefly attributed to prevalence of PLB and SLB in almost all the onion cultivated areas of Northern and Eastern regions (Gupta et al., 1996; Suhag and Bhatia, 2006). Although, Purple Leaf Blotch and Stemphylium leaf blight are common on both bulb as well as seed crop of onion, yet it is more damaging particularly in latter, every year in Punjab. The attack is common during March-April coinciding with the bolting of the crop and it may cause 35 to 100 per cent losses (Sharma, 1986). Being weather preferences similar for both PLB and SLB, they mostly occur synchronously on the same umbel bearing stalk resulting additive loss. The typical oval to elliptical lesions were colonised by either Alternaria porri, Stemphylium vesicarium or mixtures of both pathogens (Suheri and Price, 2001). The lesions containing $A$. porri alone or S.vesicarium alone or mixture of both were generally impossible to be differentiated from each other and thus, it was considered to be a complex problem (Suheri and Price 2000a, b).
Krishi Vigyan Kendra, Faridkot has been associated with seed production of onion var. PRO 6 since 2012-13. Generally, bulb to seed method was employed for raising seed crop of onion. During initial years, the seed yield was quite meager to the tune of $1.1 \mathrm{q} / \mathrm{ha}$. It was due to limited availability of effective fungicides against purple blotch complex. A good number of fungicides were yet to be evaluated against this disease. Thus, the present study was undertaken to screen out the effective fungicides for the management of the purple blotch complex of onion for seed production.

\section{Materials and Methods}

Field efficacy of four systemic fungicides viz., Tilt 25 EC (propiconazole), Folicur 25 EC (tebuconazole), Score 25 EC (difenoconazole) @ 0.1 percent, Amistar Top 325 SC (azoxystrobin $18.2 \%+$ difenoconazole $11.4 \%) @ 0.05$ per cent, and one nonsystemic fungicides viz., Indofil M-45 75 WP (mancozeb) @ 0.3 per cent, were determined in controlling the onion PBC under field conditions on seed crop (cv. PRO-6) during the Rabi season 2015-16 and 2016-2017.

The field trial was conducted in Randomized Block Design (RBD) with six treatments along with four replications. All the recommended agronomical practices were followed during experimentation. The bulbs were planted during first fortnight of November at spacing of $67.5 \mathrm{~cm} \mathrm{X} 45 \mathrm{~cm}$. Foliar application of fungicides was started as soon as first symptom of the disease was noticed followed by three sprays at 15 days interval in bulb seed crop.

Twenty-five plants from each plot were randomly tagged for disease assessment on the 0 to 5 rating scale given by Sharma (1986) as follows: 


\begin{tabular}{|l|l|}
\hline Score & Disease description \\
\hline $\mathbf{0}$ & $\begin{array}{l}\text { A few disease symptom } \\
\text { area }\end{array}$ \\
\hline $\mathbf{1}$ & $\begin{array}{l}\text { Several purplish brown patches } \\
\text { covering up to } 20 \text { per cent of leaf } \\
\text { area }\end{array}$ \\
\hline $\mathbf{3}$ & $\begin{array}{l}\text { Several patches with paler outer zone } \\
\text { covering up to } 40 \text { per cent leaf area }\end{array}$ \\
\hline $\mathbf{4}$ & $\begin{array}{l}\text { Leaf streaks covering up to } 75 \text { per } \\
\text { cent leaf area or breaking of the } \\
\text { leaves from center }\end{array}$ \\
\hline $\mathbf{5}$ & $\begin{array}{l}\text { Complete drying of the leaves or } \\
\text { breaking of leaves from center }\end{array}$ \\
\hline
\end{tabular}

The observations on disease severity were recorded 10 days after last fungicidal spray. Data were collected on leaf infection and percent Leaf Area Diseased (LAD) and calculated in terms of disease incidence and disease severity (PDI) by following formulae

Disease incidence $=$

Number of infected leaves

$\longrightarrow$ X 100

Total number of inspected leaves

$\mathrm{PDI}=$

Total sum of numerical ratings

Number of $X \quad$ Maximum disease observation rating in the scale

\section{Results and Discussion}

The data presented in Table 1 depicts the effect of different fungicides on the disease incidence and severity of purple blotch complex of onion All the treatments significantly reduced the per cent disease index as compared to control. Systemic triazole and strobilurin fungicides were found more effective as compared to non-systemic fungicides. Among them, tebuconazole $25 \mathrm{EC}$ @ $0.1 \%$ was found significantly superior over the rest of treatments, showing minimum $(11.23 \%)$ purple blotch intensity .The next best treatment was difenoconazole 25 EC @ $0.1 \%(19.13 \%)$ followed by propiconazole 25 EC@ $0.1 \%$ which showed disease intensity of $24.69 \%$ and Azoxystrobin $18.2+$ difenoconazole 11.4 SC @ $0.05 \%$, which recorded disease intensity of $34.03 \%$. Treatment with Mancozeb 75 WP @ $0.3 \%$ was the least effective recording disease intensity of 39.88 per cent. Tebuconazole 25 EC @ $0.1 \%$ recorded the highest per cent disease control to the tune of 83.72 per cent followed by difenoconazole 25 EC @ $0.1 \%$ (72.28\%), propiconazole 25 EC @ $0.1 \%$ $(64.22 \%)$ and Azoxystrobin $18.2+$ difenoconazole 11.4 SC @ $0.05 \%$ (50.69\%). Tebuconazole, difenoconazole and propiconazole are fungicides of triazole group. They cause demethylation of C-14 during ergosterol biosynthesis leading to accumulation of C-14 methyl sterols. The biosynthesis of these ergosterols is critical to the formation of cell walls of fungi. Lack of normal sterol production slower down or stops the growth of the fungus preventing further infection and/or invasion of host tissues. The least effective fungicide was the non systemic Mancozeb 75 WP @ $0.3 \%$ which recorded mediocre disease control of $42.21 \%$. The present findings are in close agreement with those earlier reported by Upamanyu (1999), Deshmukh et al., (2007), Beig et al., (2008), Aujila et al., (2010), Aujila et al., (2013) and Bhatia and Chahal (2014), who have also reported the superiority of tebuconazole, propiconazole and difenoconazole over conventional fungicides in controlling the disease. Similarly, the present findings are also in agreement with earlier reported by Vincelli (2002), Nelson and Meinhardt (2011), Henry et al., (2011) and Hill et al., (2013) who have also reported 
the growth promoting effects of strobilurins in several plant species.

The data presented in Table 2 reveals that the highest seed yield was recorded in tebuconazole $25 \quad$ EC $(3.37 \quad \mathrm{q} / \mathrm{ha})$ and difenoconazole $25 \mathrm{EC}(3.10 \mathrm{q} / \mathrm{ha})$. Both these treatments were statistically superior over propiconazole $25 \mathrm{EC}$ and Azoxystrobin 18.2 + difenoconazole 11.4 SC which recorded seed yield of $2.72 \mathrm{q} / \mathrm{ha}$ and $2.61 \mathrm{q} / \mathrm{ha}$, respectively. All the systemic fungicidal treatments resulted in much higher increase in benefit: cost (B: C) ratio over non- systemic one. The highest $\mathrm{B}$ : $\mathrm{C}$ ratio was recorded in tebuconazole (91.9:1), while the lowest B: C ratio was recorded in Mancozeb 75 WP (51.6:1). The present findings revealed that higher disease control recorded by tebuconazole in onion seed crop could be attributed to growth promoting effects of triazoles.

Table.1 Effect of fungicides on the disease incidence and severity of purple blotch complex of onion

\begin{tabular}{|l|c|c|c|}
\hline Treatments & $\begin{array}{c}\text { Concentration } \\
(\boldsymbol{\%})\end{array}$ & $\begin{array}{c}\text { Percent } \\
\text { disease index }\end{array}$ & $\begin{array}{c}\text { \% disease control } \\
\text { untreated control }\end{array}$ \\
\hline Propiconazole 25 EC & 0.1 & 24.69 & 64.22 \\
\hline Tebuconazole 25 EC & 0.1 & 11.23 & 83.72 \\
\hline Difenoconazole 25 EC & 0.1 & 19.13 & 72.28 \\
\hline $\begin{array}{l}\text { Azoxystrobin 18.2 + difenoconazole 11.4 } \\
\text { SC }\end{array}$ & 0.05 & 34.03 & 50.69 \\
\hline Mancozeb 75 WP & 0.3 & 39.88 & 42.21 \\
\hline Untreated control & - & 69.01 & - \\
\hline C.D. (P= 0.05) & & 5.55 & - \\
\hline
\end{tabular}

Table.2 Effects of fungicides on yield and economics of onion cultivation against purple blotch disease

\begin{tabular}{|l|c|c|c|c|}
\hline Treatments & $\begin{array}{c}\text { Concentration } \\
(\mathbf{\%})\end{array}$ & $\begin{array}{c}\text { Seed yield } \\
(\mathbf{q} / \mathbf{h a})\end{array}$ & $\begin{array}{c}\text { \% increase in seed } \\
\text { yield over } \\
\text { untreated control }\end{array}$ & $\begin{array}{c}\text { Additional } \\
\text { Benefit: Cost } \\
\text { over control }\end{array}$ \\
\hline Propiconazole 25 EC & 0.1 & 2.72 & 147.27 & $81.8: 1$ \\
\hline Tebuconazole 25 EC & 0.1 & 3.37 & 206.36 & $91.9: 1$ \\
\hline Difenoconazole 25 EC & 0.1 & 3.10 & 181.81 & $81.3: 1$ \\
\hline $\begin{array}{l}\text { Azoxystrobin 18.2 + } \\
\text { difenoconazole 11.4 SC }\end{array}$ & 0.05 & 2.61 & 137.27 & $61.9: 1$ \\
\hline Mancozeb 75 WP & 0.3 & 2.03 & 84.55 & $51.6: 1$ \\
\hline Untreated control & - & 1.10 & - & \\
\hline C.D. (P= 0.05) & & 0.21 & - & \\
\hline
\end{tabular}


Tabl.3 Effect of different fungicides on the $\%$ of seed germination of harvested seeds of onion

\begin{tabular}{|l|c|c|c|}
\hline Treatments & $\begin{array}{c}\text { Concentration } \\
(\boldsymbol{\%})\end{array}$ & $\begin{array}{c}\text { \% Seed } \\
\text { germination }\end{array}$ & $\begin{array}{c}\text { \% increase seed } \\
\text { germination over } \\
\text { control }\end{array}$ \\
\hline Propiconazole 25 EC & 0.1 & 85.09 & 23.7 \\
\hline Tebuconazole 25 EC & 0.1 & 89.66 & 30.3 \\
\hline Difenoconazole 25 EC & 0.1 & 86.82 & 26.2 \\
\hline $\begin{array}{l}\text { Azoxystrobin 18.2 + } \\
\text { difenoconazole 11.4 SC }\end{array}$ & 0.05 & 86.64 & 25.9 \\
\hline Mancozeb 75 WP & 0.3 & 73.73 & 07.2 \\
\hline Untreated control & - & 68.80 & \\
\hline C.D. $(\mathbf{P = 0 . 0 5 )}$ & & 6.82 & \\
\hline
\end{tabular}

The data presented in Table 3 for post harvest seed health testing after treating standing onion seed crop with fungicidal spraying depicts that under in vitro test, the highest seed germination was recorded in the seed sample picked up from tebuconazole 25 EC treated plot $(89.66 \%)$, which was followed by difenoconazole 25 EC $(86.82 \%)$, Azoxystrobin $18.2+$ difenoconazole 11.4 SC (86.64\%) and propiconazole 25 EC (85.09 $\%)$. All the treatments differed significantly from the control (68.8\%) and mancozeb 75 WP $(73.73 \%)$ treated plot. No previous results are available in the literature regarding the post harvest seed health testing after treating standing crop (onion) with fungicidal spraying.

\section{References}

Ahmed, H.U. and Hossain, M.M (1985) Final report of project crop disease survey and establishment of a herbarium at BARI, Plant Path. Divn., BARI, Joydepber, Gazipur, Bangladesh. 1670 pp.

Anonymous (2017). Horticultural Statistics at a Glance, 2017, Pp. 16, 454 and 470.

Aujila IS, Amrate PK, Kumar P and Thind TS (2013) Efficacy of some new fungicides in controlling purple blotch of onion under Punjab conditions. Plant Disease
Research 28: 171- 173.

Aujila IS, Goswami S, Thind TS, Raheja S and Kumar P (2010) Relative effectiveness of fungicides in controlling purple blotch of onion seed crop. Plant Disease Research 25: 7374.

Beig MA, Bhat NA and Maheshwari SK (2008) Evaluation of different fungicides against purple blotch of onion under Kashmir conditions. Plant Disease Research 22: 34-36.

Bhatia JN and Chahal D (2014) Studies on effectiveness of certain new fungicides in controlling Stemphylium blight of onion seed crop. Agric Sci Digest 34: 237-239.

Cramer CS (2000) Breeding and Genetics of Fusarium basal rot resistance in Onion. Euphytica 115: 159-166.

Deshmukh VS, Dhruj IU and Chavan RV (2007) Chemical control of Purple blotch (Alternaria porri) (Ellis) Cif. of onion. Plant Disease Research 22: 3436.

Gupta RP, Srivastava PK and Sharma RC (1996) Efficacy of fungicides and their spray interval on the control of purple blotch and Stemphylium blight diseases of onion. NHRDF Newsl 16: 11-13.

Henry RS, Johnson WG and Wise KA (2011) The impact of a fungicide and an 
insecticide on soybean growth, yield, and profitability. Crop Prot 30: 16291634

Hill CB, Bowen CR and Hartman GL (2013) Effect of fungicide application and cultivar on soybean green stem disorder. Plant Dis 97: 1212-1220.

Munoz, D.C.L.; Martinez, J.J.P. and Perez, A.P. 1984. Onion seed production under tropical conditions. Humbalst Inst. Fund. Res. Trop. Agric. Acad. Sci. 10(2): 42-45.

Nelson KA and Meinhardt CG (2011) Foliar Boron and Pyraclostrobin effects on corn yield. Agron J 103: 1352- 1358.

Purseglove JW (1972) Tropical crops: Monocotyledons. Longman Press, London.

Sharma SR (1986) Effect of fungicides on purple blotch and bulb yield of onion. Indian Phytopath 39: 78-82.

Suhag LS and Bhatia JN (2006) Stemphylium blight of Onion- A review in Seed Technology and Seed Pathology. Pointer Publisher, Jaipur, Rajasthan,
India. pp. 392-412.

Suheri H and Price TV (2000a) Infection by Alternaria porri and Stemphylium vesicarium on onion leaves and disease development under controlled environments. Plant Pathol 49: 377384.

Suheri H and Price TV (2000b) Stemphylium leaf blight of garlic (Allium sativum) in Australia. Australas Plant Pathol 29: 192-199.

Suheri $H$ and Price TV (2001) The epidemiology of purple leaf blotch on leeks in Victoria, Australia. Eur J Plant Pathol 107: 503-510.

Upamanyu S (1999) Studies on purple blotch of onion caused by Alternaria porri (Ellis) Cif. M.Sc. Thesis, Dr. Y. S Parmar University of Horticulture and Forestry, Solan, India.

Vincelli P (2002) QoI (Strobilurin) Fungicides: Benefits and Risks. The Plant Health Instructor. DOI: 10.1094/PHI-I-2002-0809-02

\section{How to cite this article:}

Gurdarshan Singh and Jagdish Grover. 2020. Management of Purple Blotch Complex in Onion Seed Crop in Faridkot district of South-Western Punjab. Int.J.Curr.Microbiol.App.Sci. 9(02): 2400-2405. doi: https://doi.org/10.20546/ijcmas.2020.902.273 